\title{
Terapi akupresur sebagai evidence based nursing untuk mengurangi nyeri dada pada pasien sindrom koroner akut
}

\author{
Irwan Surya Wibisono Kambu', Beti Kristinawati ${ }^{2}$, Sigit Shalihien ${ }^{3}$ \\ ${ }^{1}$ Mahasiswa Profesi Ners, Program Studi Ilmu Keperawatan, Fakultas Ilmu Kesehatan, Universitas Muhammadiyah \\ Surakarta \\ ${ }^{2}$ Departemen Keperawatan Bedah, Program Studi Ilmu Keperawatan, Fakultas Ilmu Kesehatan, Universitas \\ Muhammadiyah Surakarta \\ ${ }^{3}$ Perawat Senior, Rumah Sakit Umum Pusat dr. Soeradji Tirtonegoro Klaten
}

Keywords :

Nyeri dada, akupresur, sindrom koroner akut

\section{Kontak :}

Irwan Surya Wibisono Kambu Email : irwanpunya39@gmail.com

Program Studi Ilmu Keperawatan, Fakultas Ilmu Kesehatan, Universitas Muhammadiyah Surakarta

DOI : https://doi.org/10.15294/

kemas.v14i3.1562

\section{(c)2020J-Healt}

ini adalah artikel dengan akses terbuka dibawah licenci CC BY-NC-4.0

https://creativecommons.org/licenses/by-nc/4.0/

\begin{abstract}
Abstrak
Penyakit jantung koroner secara klinis ditandai dengan nyeri dada akibat sumbatan di arteri coroner. Akupresur merupakan bagian terapi komplementer yang mampu meningkatkan kadar endorfin untuk merangsang penurunan nyeri. Pelaksanaan evidence based nursing akupresur ini diberikan pada 8 pasien dengan teknik pemilihan purposive sampling. Instrument penerapan menggunakan skala penilaian nyeri visual analog scale. Penerapan akupresur diberikan selama 20 menit pada titik akupresur L14 dengan skala nyeri 0 sampai 5. Hasil dari 8 sampel yang diberikan akupresur semua pasien mengalami penurunan skala nyeri. Penekanan atau sentuhan pada titik akupresur dapat meningkatkan kadar endorfin dalam darah maupun sistemik. Endorfin merupakan opiat tubuh secara alami dihasilkan oleh kelenjar pituitary yang berguna untuk mengurangi nyeri, mempengaruhi memori dan mood yang kemudian akan memberikan perasaan relaks. Terapi akupresur terbukti mampu menurunkan nyeri sehingga bermanfaat untuk diterapkan pada pasien akut koroner sindrom dengan keluhan nyeri dada.
\end{abstract}

\begin{abstract}
Coronary heart disease is clinically characterized by chest pain due to a blockage in the coronary arteries. Acupressure is part of complementary therapy that is able to increase endorphin levels to stimulate pain reduction. The implementation of evidence based nursing acupressure was given to 8 patients with a purposive sampling technique. The application instrument uses a visual analog pain scale rating scale. The application of acupressure was given for 20 minutes at the L14 acupressure point with a pain scale of 0 to 5. The results of the 8 samples given acupressure all patients experienced a decrease in pain scale. Emphasis or touch on the acupressure point can increase blood and systemic endorphin levels. Endorphins are the body's opiates naturally produced by the pituitary gland which are useful for reducing pain, affecting memory and mood which will then relax. Acupressure therapy has been proven to reduce pain so it is useful to apply to acute coronary syndrome patients with chest pain.
\end{abstract}




\section{PENDAHULUAN}

Penyakit kardiovaskuler adalah penyakit yang disebabkan gangguan fungsi jantung dan pembuluh darah. Salah satu penyakit jantung yang sering terjadi adalah ACS (Acute Coronary Syndrome) yang merupakan bagian dari penyakit jantung koroner/PJK. Bagian dari ACS meliputi angina pektoris tidak stabil (Unstable Pectoris/UAP), infark miokard dengan ST Elevasi (ST Elevation Myocard Infarct (STEMI), dan infark miokard tanpa ST Elevasi ( Non ST Elevation Myocard Infarct/STEMI (Smit \& Lochner, 2019).

Penyakit jantung Acute Coronary Syndrome secara klinis ditandai dengan adanya nyeri dada (angina) atau dada terasa tertekan ketika beraktivitas. Mekanisme nyeri dada pada pasien jantung disebabkan oleh adanya sumbatan diarteri koroner atau penurunan curah jantung, akibatnya suplai darah yang membawa oksigen dan nutrisi yang dibutuhkan tubuh untuk metabolisme menurun.

Penggunaan yang tepat dari analgesik atau dengan kombinasi merupakan penatalaksanaan yang paling efektif untuk menurunkan intensitas nyeri. Namun, pada kenyataannya tidak semua nyeri dapat diintervensi dengan analgetik sistemik bahkan beberapa penelitian menunjukkan hasil yang kurang baik pada penggunaan obat-obat penurun rasa nyeri (Brown, 2014). Ketakutan akan terjadinya ketergantungan dan efek samping dapat membatasi klien menghentikan penggunaan analgetik. Sebagai contoh obat tramadol yang merupakan opioid sintetis memiliki efek samping mual, muntah, konstipasi, dan konfusi pada lansia. Obat antiinflamasi non-steroid (NSAID) dapat menyebabkan dispepsia, perdarahan lambung, ulkus peptikum, perdarahan abnormal, kerusakan saluran cerna, dan nefritis ginjal akut sehingga diperlukanya penatalaksanaan non-farmakologis untuk dapat diterapkan sebagai pengganti intervensi atau kombinasi dalam menurunkan intensitas nyeri (Kneale \& Davis, 2011).
Akupresur merupakan salah satu terapi komplementer berdasarkan pada teori keseimbangan yang bersumber dari isi alam raya dan sifat-sifatnya yang disebut Yin dan Yang. Pelaksanan akupresur dilakukan dengan memberikan tekanan fisik pada beberapa titik pada permukaaan tubuh yang merupakan tempat sirkulasi energi dan keseimbangan pada kasus gejala nyeri. Kelebihan teknik akupresur yaitu aman, mudah, praktis, tidak memerlukan biaya besar, tidak menimbulkan efek samping dan bisa dilakukan siapa saja (Widyaningrum, 2013).

Berdasarkan penelitian yang dilakukan Narimani et al pada tahun 2018 memperlihatkan hasil bahwa akupresure diberikan pada kelompok intervensi pada titik L14 terbukti signifikan dalam mengurangi keluhan nyeri dada pada pasien dengan penyakit jantung.

Menurut hasil observasi di ruang ICCU RSUP dr. Soeradji Tirtonegoro Klaten pada tanggal 18-30 november 2019 terdapat 12 pasien dengan keluhan nyeri dada skla 0-5 (0-10) menggunakan skala pengukuran VAS (viasual analog scale)

Penatalaksanaan pada pasien yang dirawat di ruang ICCU RSST Klaten terdiri dari management farmakologi tahap awal seperti penggunaan obat-obat morfin, nitrat, aspirin kemudian untuk kasus ST Elevation Myocard Infarct/STEMI menggunakan jenis pengobatan fibrinolysis/referfus. Selain itu juga perawat melakukan terapi nonfarmakologi mandiri perawat seperti teknik distraksi dan relaksasi.

Tujuan terapi akupresure ini adalah untuk mengurangi nyeri dada pada pasien dengan penyakit akut coronary sindrom yaitu dengan menggunakan teknik akupresure.

Berdasarkan latarbelakang yang telah dijelasakan diatas maka penulis ingin menerapkan terapi akuptresur sebagai evidence based nursing untuk mengurangi nyeri dada pada pasien sindrom coroner akut. 


\section{METODE}

Penerapan Evidence Based Nursing (EBN) diawali dengan penentuan fenomena aktual yang terjadi di ruangan kemudian dilakukan pencarian terhadap jurnal-jurnal yang sesuai untuk memberikan solusi intervensi.

Pencarian jurnal elektronik internasional menggunakan mesin pencari menggunakan google scholar, pubmed, researchgate, national center for biotechnology information dengan kata kunci acupressure, chest pain, acute coronary syndrome, nyeri dada, terapi akupresur, sindrom coroner akut. Jurnal kemudian dipilah sesuai dengan topik sehingga terkumpul 9 jurnal internasional yang dianggap dapat mewakili dari keseluruhan jurnal tentang akupresur dalam menurunkan nyeri.

Berikutnya menentukan 1 jurnal beserta jurnal pendukung untuk dijadikan sebagai dasar dalam penerapan. Penerapan EBN ini menggunakan desain teknik pemilihan purposive sampling. Instrument penerapan menggunakan skala penilaian nyeri visual analog scale/ VAS Pelaksanaan dilakukan di ruangan rawat inap Intensive Cardiovaskuler Care Unit RSUP dr. Soeradji Tirtonegoro Klaten. Tahap observasi serta pencarian literatur dimulai pada tanggal 4 - 30 November 2019. Jumlah populasi berjumlah 12 pasien dengan responden yang diteliti berjumlah 8 orang pasien. Intervensi terapi akupresur/sentuhan diberikan pada lokasi titik LI4 terletak di bagian belakang tangan kanan/kiri antara tulang metacarpal pertama dan kedua dan hampir sepanjang tulang radial. Dilakukan selama \pm 20 menit dalam 10 detik diberikan tekanan sekitar 3 - 5 kilogram dengan periode istirahat 2 detik.

Identifikasi sampel yang terlibat dalam penerapan EBN menggunakan kriteria inklusi dan eksklusi yaitu tidak ada riwayat penggunaan akupresur untuk tujuan apa pun, tidak adanya bekas luka, goresan, cacat pada titik akupresur, kemampuan berbicara dan memahami bahasa baik, keluhanyan nyeri dalam rentan nyeri sedang (0-5), indeks masa tubuh (IMT) dalam batas normal, tidak ada riwayat operasi jantung, penyakit psikologis dan kecanduan alkohol atau obat-obatan. Berikutnya kriteria ekslusi yaitu pasien menolak dijadikan sampel, rasa panas, kemerahan, pembengkakan serta mati rasa pada titik akupresur, pasien yang mengalami fraktur tulang rusuk atau vertebra, luka bakar dan pasien terpasang peralatan invasive pada titik akupresure.

\section{HASIL}

Dalam penerapan EBN ini, pasien yang terlibat adalah sebanyak 8 orang pasien. Karakteristik dan hasil penerapan EBN yang dilakukan pada pasien adalah sebagai berikut:

Tabel 1

Karakteristik Responden

\begin{tabular}{llll}
\hline No & Karakteristik & Frekuensi & $\%$ \\
\hline 1 & Jenis Kelamin & & \\
& Perempuan & 5 & 62,5 \\
& Laki-laki & 3 & 37,5 \\
& & & \\
\hline 2 & Umur responden & & \\
& $\leq 45$ Tahun & 1 & 12,5 \\
& $\geq 65$ Tahun & 7 & 87,5 \\
\hline 4 & Diagnosa medis & & \\
& NSTEMI & 5 & 62,5 \\
& UAP & 1 & 12,5 \\
& STEMI & 2 & 25 \\
\hline
\end{tabular}

Beradarkan hasil tabel diatas diproleh hasil bahwa paling banyak berjenis kelamin perempuan yaitu 5 responden $(62,5 \%)$ sedangkan untuk jenis kelamin laki-laki berjumlah 3 responden $\quad(37,7 \%)$ Karakteristik umur paling banyak usia $\geq 65$ tahun berjumlah 7 responden $(87,5 \%)$ dan untuk umur $\leq 45$ tahun berjumlah 1 responden $(12,5 \%)$. Kemudian berdasarkan jumlah diagnosa paling banyak yaitu NSTEMI berjumlah 5 kasus $(62,5 \%)$, STEMI 2 kasus (25\%) dan UAP (12,5\%). 
Tabel 2

Observasi Perubahan Skla Nyeri

\section{Skala nyeri}

\begin{tabular}{ccc} 
Rerata & Pre test & Post test \\
\hline 4 & 2
\end{tabular}

Berdasarkan tabel 2 didapatkan bahwa perubahan skala nyeri menggunakan Visual Analog Scale/VAS yang diberikan intervensi terapi akupresur melaporkan rata-rata pre test $4(0-10)$ dan post tets $2(0-$ 10).

\section{PEMBAHASAN}

Nyeri merupakan suatu sensasi yang ditangkap oleh medulla spinalis kemudian diterima oleh medulla oblongata dan diterjemahkan sebagai suatu sensasi yang tidak enak pada saraf pusat yang dapat dijelaskan melalui suatu teori gate control. Dengan memberikan tekanan fisik pada titik L14 pada permukaaan tubuh yang merupakan tempat sirkulasi energi dan keseimbangan pada kasus gejala nyeri dapat meningkatkan kadar endofrin dalam darah maupun sistemik, tetapi memiliki daerah tangkap yang berbeda, sehingga penggunanan titik akupresur berbeda sesuai dengan organ yang akan dituju dan sesuai indikasi. Endofrin merupakan opiat tubuh secara alami dihasilkan oleh kelenjar pituitary yang berguna untuk mengurangi nyeri, mempengaruhi memori dan mood yang kemudian akan memberikan perasaan relaks (Yam et al, 2018).

Dalam penerapan teknik akupresur ini terjadi pelaporan skala penurunan nyeri dada pada 7 responden dengan skor ratarata penurunan nyeri 2 , ini menunjukan bahwa akupresur mampu menurunkan skala nyeri dada pada pasien dengan dengan kasus Acute Coronary Syndrome/ACS. Menurut beberapa hasil pembahasan dari 15 studi tentang terapi akupresur 12 studi terbukti secara signifikan mampu menurunkan nyeri setelah pemberian terapi akupresur (You et al, 2017).

Pada hasil penerapan terdapat 1 responden melaporkan tidak terjadi skala penurunan nyeri setelah dilakukan terapi akupresur. Pada kasus ini pasien terdiagnosa STEMI dengan on site nyeri dada lebih dari 12 jam. Menurut Perhimpunan Dokter Spesialis Kardiovaskular Indonesia (PERKI) penatalaksanaa terapi fibrinolitik IMA STE akut secara dini diberikan dalam waktu on site 12 jam sejak awitan dapat mengembalikan aliran darah sebesar $70 \%$ sampai $80 \%$ pada koroner yang mengalami oklusi dan secara signifikan dapat mengurangi kerusakan jaringan. Namun demikian sebaliknya apabila penyumbatan arteri tidak segara diatasi maka akan terjadi kematian sel miokardium akibat proses iskemik yang berkepanjangan ditandai dengan keluhan nyeri dada yang berkelanjutan.

\section{KESIMPULAN}

Penerapan terapi akupresur yang dilakukan pada pasien Acute Coronary Syndrome/ACS dengan keluhan nyeri dada mampu memberikan manfaat mengurangi nyeri, sehingga dapat menurunkan peluang terjadinya ketergantungan serta dampak efek samping pengobatan dan berdampak menurunkan hari perawatan pasien.

\section{Daftar Pustaka}

Narimani M, Ansari Jaberi A, Negahban Bonabi T, Sadeghi T. Effect of Acupressure on Pain Severity in Patients Undergoing Coronary Artery Graft: A Randomized Controlled Trial. Anesth Pain Med. 2018;8(5):e82920. Published 2018 Oct 20. doi:10.5812/aapm. 82920

Yeh CH, Chiang YC, Hoffman SL, et al. Efficacy of auricular therapy for pain management: a systematic review and meta-analysis. Evid Based Complement Alternat Med. 2014;2014:934670. 
doi:10.1155/2014/934670

You, Eunhea \& Kim, David \& Harris, Ryan \& D'Alonzo, Karen. (2018). Effects of Auricular Acupressure on Pain Management: A Systematic Review. Pain Management Nursing. 20. 10.1016/j.pmn.2018.07.010.

Bergmann N, Ballegaard S, Bech $\mathrm{P}$, Hjalmarson A, Krogh J, Gyntelberg F, et al. (2014) The Effect of Daily SelfMeasurement of Pressure Pain Sensitivity Followed by Acupressure on Depression and Quality of Life versus Treatment as Usual in Ischemic Heart Disease: A Randomized Clinical Trial. PLoS ONE 9(5): e97553. https://doi.org/10.1371/journal.pone.009 7553

Mehta P, Dhapte V, Kadam S, Dhapte V. Contemporary acupressure therapy: Adroit cure for painless recovery of therapeutic ailments. $J$ Tradit Complement Med. 2016;7(2):251-263. Published 2016 Jul 22. doi:10.1016/j.jtcme.2016.06.004

Yam MF, Loh YC, Tan CS, Khadijah Adam S, Abdul Manan N, Basir R. General Pathways of Pain Sensation and the Major Neurotransmitters Involved in Pain Regulation. Int $J$ Mol Sci. 2018;19(8):2164. Published 2018 Jul 24. doi:10.3390/ijms19082164

Brown, A. 2014. Strategies To Reduce Or Eliminate Wound Pain. Nursing Times. 110(15), $12-$ 15.[Online].http://www.nursingtimes.ne t/Journals/2014/04/04/h/k/k/Strategiesto-reduceor-eliminate-wound-pain090414.pdf.

Kneale, JD \& Davis, PS. 2011. Keperawatan Ortopedik dan Trauma. Edisi 2. Jakarta: Penerbit buku kedokteran EGC

Treede RD. The International Association for the Study of Pain definition of pain: as valid in 2018 as in 1979, but in need of regularly updated footnotes. Pain Rep. 2018;3(2):e643. Published 2018 Mar 5.
doi:10.1097/PR9.0000000000000643

Widyaningrum, H. (2013). Pijat refleksi \& 6 terapi alternatif lainnya. Jakarta: Media Pressindo

Smit, M., Coetzee, A. R., \& Lochner, A. (2019). The Pathophysiology of Myocardial Ischemia and Perioperative Myocardial Infarction. Journal of Cardiothoracic and Vascular Anesthesia. https://doi.org/10.1053/j.jvca.2019.10.0 05 